\title{
Comparison between the Protective Effects of Famotidine, Ginger and Marshmallow on Pyloric Ligation-Induced Peptic Ulcer in Rats
}

\section{Zaghlool SS ${ }^{1 *}$, Shehata BA ${ }^{2}$, Abo-Seif $A^{1}$ and El-Latif HAA}

${ }^{1}$ Pharmacology and Toxicology Department, Nahda University, Egypt

${ }^{2}$ Pharmacology and Toxicology Department, Beni-Sueif University, Egypt

${ }^{3}$ Pharmacology and Toxicology Department, Umm Al-Qura University, KSA

\begin{abstract}
Background: Gastric ulcer is one of the most serious diseases over wide the world. There are many drugs used for the treatment of gastric ulcer, but most of these produce several adverse reactions. This study aims to investigate the protective effects of extracts of ginger and marshmallow on pyloric ligation-induced gastric ulcer in rats.

Methods: Animals were divided into 5 Groups; a normal control group, an ulcer control group, a standard treatment group receiving famotidine $(20 \mathrm{mg} / \mathrm{kg})$, and two treatment groups receiving ginger $(100 \mathrm{mg} / \mathrm{kg})$ and marshmallow $(100 \mathrm{mg} / \mathrm{kg})$. Treatments were given orally for 14 days. On the $15^{\text {th }}$ day, animals were subjected to pyloric ligation except for the normal control group. Four hours later, rat stomachs were excised and gastric juice and blood samples were collected.

Results: Pyloric ligation caused significant elevations in ulcer number, ulcer index, gastric volume, titratble acidity, acid output, mucin content and peptic activity, accompanied by significant decreases in blood superoxide dismutase (SOD) activity and gastric mucosal nitric oxide (NO) and glutathione (GSH) contents. In addition, elevations in gastric mucosal lipid peroxide and histamine contents were observed. Pretreatment with famotidine, ginger or marshmallow significantly corrected all blood and tissue parameters by varying degrees.
\end{abstract}

Conclusions: Famotidine, ginger and marshmallow may protect against pyloric ligation-induced peptic ulcer in rats, being promising for further clinical trials.

Keywords: Famotidine; Ginger; Marshmallow; Peptic ulcer; Pyloric ligation

\section{Introduction}

Peptic ulcer is one of the world's major gastro-intestinal disorders, embracing both gastric and duodenal ulcers, and affecting $10 \%$ of the world population [1]. The pathogenesis of peptic ulcer disease includes a complex imbalance between gastric offensive factors like increased gastric acid and pepsin secretion, Helicobacter pylori $(H$. Pylori) infection, bile salts, ethanol, medications like NSAIDs, and lipid peroxidation, and defensive mucosal factors like prostaglandins (PG's), gastric mucus, cellular renovation, blood flow, mucosal cell shedding, glycoproteins, mucin secretion, proliferation and antioxidant defense mechanisms like catalase (CAT), superoxide dismutase (SOD), nitric oxide (NO) and glutathione (GSH) [1].

Famotidine is an $\mathrm{H}_{2}$ receptor antagonist that inhibits acid production by reversibly competing with histamine for binding with $\mathrm{H}_{2}$ receptors located at the basolateral membrane of the parietal cells [2-4]. Histamine $\mathrm{H}_{2}$ receptor antagonists not only inhibit acid secretion induced by histamine, gastrin and cholinergic stimulation, but can also promot healing of ulcers $[5,6]$.

The use of phytoconstituents as drug therapy to treat major ailments has proved to be clinically effective and relatively less toxic than traditional drugs, based on their ability to reduce offensive factors, particularly oxidative stress [7]. Ginger (Zingiber officinale Roscoe, family: Zingiberaceae) is a herbal drug reported to stimulate digestion and absorption and to relieve constipation and flatulence by increasing muscular activity in the digestive tract [8-10].

In folk medicine and literatures, marshmallow (Althaea officinalis L., family: Malvaceae) was used in gastrointestinal disorders [11]. Aqueous marshmallow flower extract demonstrated a protection against ethanol-induced gastric ulcer. It has been shown that mucilage and flavonoids have the property of covering and protecting gastric mucosa, thereby reducing the incidence of gastric ulcer $[12,13]$.

Based on the aforementioned data, the aim of the present study is to determine protective effects of ginger and marshmallow extracts on pyloric ligation-induced peptic ulcer in rats.

\section{Materials and Methods}

\section{Animals}

Adult male albino rats weighing 200-250 g were used in the present investigation. Animals were obtained from the animal house of Nahda University, Beni-Sueif and were kept under observation for about 15 days before the onset of the experiment to exclude any inter-current infection. The chosen animals were housed in plastic cages with good aerated covers at $25 \pm 0.5^{\circ} \mathrm{C}$ under 12 hour's light/dark periods. Animals were allowed free access of water and were supplied daily with standard forage ad libitum. All animal housing and handling were conducted in compliance with the Beni-Sueif University guidelines and in accordance with the research protocols established by the Animal

*Corresponding author: Zaghlool SS, Faculty of Pharmacy, Nahda University, Ben Sueif, Egypt, Tel: (002) 01005113065; E-mail: samehsaadzaghlool@yahoo.com

Received March 20, 2015; Accepted April 17, 2015; Published April 24, 2015

Citation: Zaghlool SS, Shehata BA, Abo-Seif AA, El-Latif HAA (2015) Comparison between the Protective Effects of Famotidine, Ginger and Marshmallow on Pyloric Ligation-Induced Peptic Ulcer in Rats. J Bioequiv Availab 7: 170-178. doi:10.4172/ jbb.1000234

Copyright: @ 2015 Zaghlool SS, et al. This is an open-access article distributed under the terms of the Creative Commons Attribution License, which permits unrestricted use, distribution, and reproduction in any medium, provided the original author and source are credited. 
Citation: Zaghlool SS, Shehata BA, Abo-Seif AA, El-Latif HAA (2015) Comparison between the Protective Effects of Famotidine, Ginger and Marshmallow on Pyloric Ligation-Induced Peptic Ulcer in Rats. J Bioequiv Availab 7: 170-178. doi:10.4172/jbb.1000234

Care Committee of the National Research Center (Cairo, Egypt) which followed the recommendations of the National Institutes of Health Guide for Care and Use of Laboratory Animals (Publication No. 85-23, revised 1985).

\section{Plant materials}

Ginger rhizomes and marshmallow flowers were purchased from Haraz Company, Cairo, Egypt and were identified phytochemically $[14,15]$ by staff members of the Department of Pharmacognosy, Faculty of Pharmacy, Nahda University.

Aqueous extract of marshmallow was prepared by soaking the dried flowers of marshmallow $(1 \mathrm{~kg})$ in hot water $\left(85-90^{\circ} \mathrm{C}\right)$ for half an hour, followed by filtration and drying of the filtrate under reduced pressure [13], with a final yield of about $11.8 \%$. The residue was dissolved in normal saline in a concentration of $100 \mathrm{mg} / \mathrm{mL}$, and kept for oral administration

Alcoholic extract of ginger was prepared by cutting rhizomes into small pieces that were completely dried in shed up for 3-4 days. Powder $(1 \mathrm{~kg})$ was obtained with the help of a mixer, and then extraction was done using $50 \%$ ethanol (v/v). The homogenate was concentrated on rotavapour (IKA"RV 10, Digital, 20-270 rpm - IKA"HB 10, Basic, $0-180^{\circ} \mathrm{C}$ - made in Germany). The residue was designated as ethanol extract $(11.5 \mathrm{~g})$. The extract was pre-solubilized in distilled water for the in vivo studies [16]. The residue was dissolved in normal saline, 100 $\mathrm{mg} / \mathrm{ml}$, and prepared for oral use.

\section{Drugs, chemicals and reagent kits}

All chemicals used in the study were of analytical grade. Famotidine was obtained as a gift from Amoun Pharmaceutical Industries Company "APIC", Cairo, Egypt. Histamine reagent kit was obtanied from Oxford Biomedical Research, Inc., USA. Malondialdehyde (MDA) reagent kit was obtanied from Cell Biolabs, Inc., USA. NO reagent kit was obtanied from Assay Designs, Inc., USA. GSH reagent kit was obtanied from Cell Biolabs, Inc., USA. SOD reagent kit was obtanied from Cell Biolabs, Inc., USA.

\section{Experimental design}

Rats were randomly allocated into 5 groups, each consisting of 6-8 rats, where test drugs or vehicles were administrated by oral feeding tube once daily for 14 days prior to induction of ulcer. Group I: received $10 \mathrm{ml} / \mathrm{kg}$ normal saline, p.o. and served as normal control group, Group II: received $10 \mathrm{ml} / \mathrm{kg}$ normal saline, p.o. and served as peptic ulcer control group, Group III: received Famotidine $(20 \mathrm{mg} / \mathrm{kg} /$ day, p.o.) $[17,18]$ and served as standard treatment group, Group IV: received ginger $(100 \mathrm{mg} / \mathrm{kg} /$ day, p.o.) $[16,19]$, and Group V: received marshmallow (100 mg/kg/day, p.o.) [13].

\section{Induction of peptic ulcer and sample preparation}

On $15^{\text {th }}$ day of drug or vehicle administration, animals were anaesthesized with urethane $(1.25 \mathrm{~g} / \mathrm{kg}$, i.p.), carefully dissected and subjected to pyloric ligation [20], except for the normal control group, after 36 hours of starvation. Four hours after pyloric ligation, animals were sacrificed by cervical dislocation under anesthesia. Stomachs were isolated and the gastric juice was collected and its volume was measured. Blood samples were collected from the retino-orbital sinus. The glandular portion of the stomach was then exposed and examined for macroscopic examination and ulcer index deterimination. Total acid output was estimated and gastric mucosal homogenates were prepared in normal saline.

\section{Assessment of gross mucosal damage}

The gastric mucosal layer was carefully inspected for the occurrence of ulcers and their numbers were counted with the aid of an illuminated magnifying lens (10X) [21,22]. The sum of the total length of long ulcers and hemorrhagic spots in each group of rats were divided by the number of animals to calculate the ulcer index $(\mathrm{mm})$. Ulcer index was calculated according to the method described by [23]. The preventive index was calculated according to the method described by [24].

$$
\text { Preventive Index }(\%)=\frac{\text { Ulcer Index }(\text { Ulcer Control group })-\text { Ulcer Index }(\text { Treated group })}{\text { Ulcer Index }(\text { Ulcer Control group })} \mathrm{X} 100
$$

Gastric volume, titratable acidity, and acid output determination

The collected gastric juice was centrifuged at $3000 \mathrm{~g}$ for $10 \mathrm{~min}$ and gastric volume $(\mathrm{ml})$ was recorded after removal of solid debris Samples having solid mass volumes more than $0.6 \mathrm{ml}$ was discarded [20]. Titratable acidity was carried out according to the method of [25] and [26] by titrating gastric juice against sodium hydroxide $(0.01 \mathrm{~N})$ using phenol red as an indicator. Acid output was calculated as the rate of the gastric juice production [27] as microequivalents per 4 hours.

$$
\text { Acid Output }(\mu E q / 4 h r)=\frac{T \times V}{4}
$$

Where: $(\mathrm{T})$ is titratable acidity $(\mathrm{mEq} / \mathrm{l})$ and $(\mathrm{V})$ is collected volume of gastric juice $(\mathrm{ml})$.

\section{Peptic activity determination}

Briefly, pepsin activity, the active principle proteolytic activity of gastric secretion was determined in terms of the amount of proteases produced after incubation of the substrate with pepsin for half an hour. The proteolytic activity of pepsin in gastric juice was determined spectrophotometrically at $280 \mathrm{~nm}$ [28].

\section{Mucin content determination}

The mucin content of the gastric juice was determined according to the method described by Winzler et al. [29]. Briefly, to diluted samples orcinol (1.6\%) and sulphuric acid $(60 \%)$ were added, vortexed and boiled for $10 \mathrm{~min}$. Mixtures were cooled in ice-cold water to stop the reaction and the absorbance was measured spectrophotometrically at $425 \mathrm{~nm}$.

\section{Determination of gastric mucosal histamine}

Histamine content of the gastric mucosa was determined according to the method described by Demoly et al. [30] and Wiley et al. [31] using enzyme immunoassay for histamine at $650 \mathrm{~nm}$.

\section{Determination of gastric mucosal GSH}

The level of GSH was determined in stomach homogenate according to the method described by Anderson et al. [32] and Halliwell et al. [33] at $405 \mathrm{~nm}$.

\section{Determination of gastric mucosal lipid peroxides} (Malondialdehyde)

Lipid peroxides were determined in gastric mucosal homogenate according to the method described by Li et al. [34] and Brindeiro et al. [35] at $532 \mathrm{~nm}$.

\section{Determination of gastric mucosal NO}

Total NO concentration was determined in gastric mucosal 
Citation: Zaghlool SS, Shehata BA, Abo-Seif AA, El-Latif HAA (2015) Comparison between the Protective Effects of Famotidine, Ginger and Marshmallow on Pyloric Ligation-Induced Peptic Ulcer in Rats. J Bioequiv Availab 7: 170-178. doi:10.4172/jbb.1000234

homogenate according to the method described by Kendrich et al. [36] at $540 \pm 20 \mathrm{~nm}$.

\section{Determination of blood SOD}

SOD activity was determined in blood according to the method described by Connell et al. [37] and Zhang et al. [38] at $490 \mathrm{~nm}$.

\section{Histopathological examination of stomach}

Hematoxylin and Eosin (H\&E) staining was used for histological examination of the general structure of the stomach [39]. The effect of drugs was evaluated through assessment of the inflammatory and necrotic changes in the mucosal tissue.

\section{Statistical analysis}

Statistical analysis and the significance of difference between group means were determined using one-way ANOVA test followed by Tukey-Kramer multiple comparisons test, using GraphPad Instat computer software, San Diego, USA. Graphs and tables were performed using Microsoft Excel 2010 computer program.

\section{Results}

\section{Preliminary phytochemical screening of extracts}

The phytochemical screening of alcoholic extract of ginger revealed the presence of carbohydrates, volatile oils, sterols, triterpenoids and alkaloids. The phytochemical screening of aqueous extract of marshmallow revealed the presence of carbohydrates, volatile oils, tanins, flavonoids, and traces of saponins.

\section{Macroscopic examination (Ulcer number, ulcer index and preventive index)}

Rats subjected to pyloric ligation (ulcer control rats) showed significant ulceration in the glandular area of their stomachs compared to normal control rats. Pretreatment with famotidine significantly reduced ulcer number and ulcer index to about $18.01 \%$ and $27 \%$, respectively, as compared to ulcer control group. Similarly, ginger pretreatment significantly reduced ulcer number and ulcer index to about $27.85 \%$ and $41.45 \%$, respectively. In addition, marshmallow
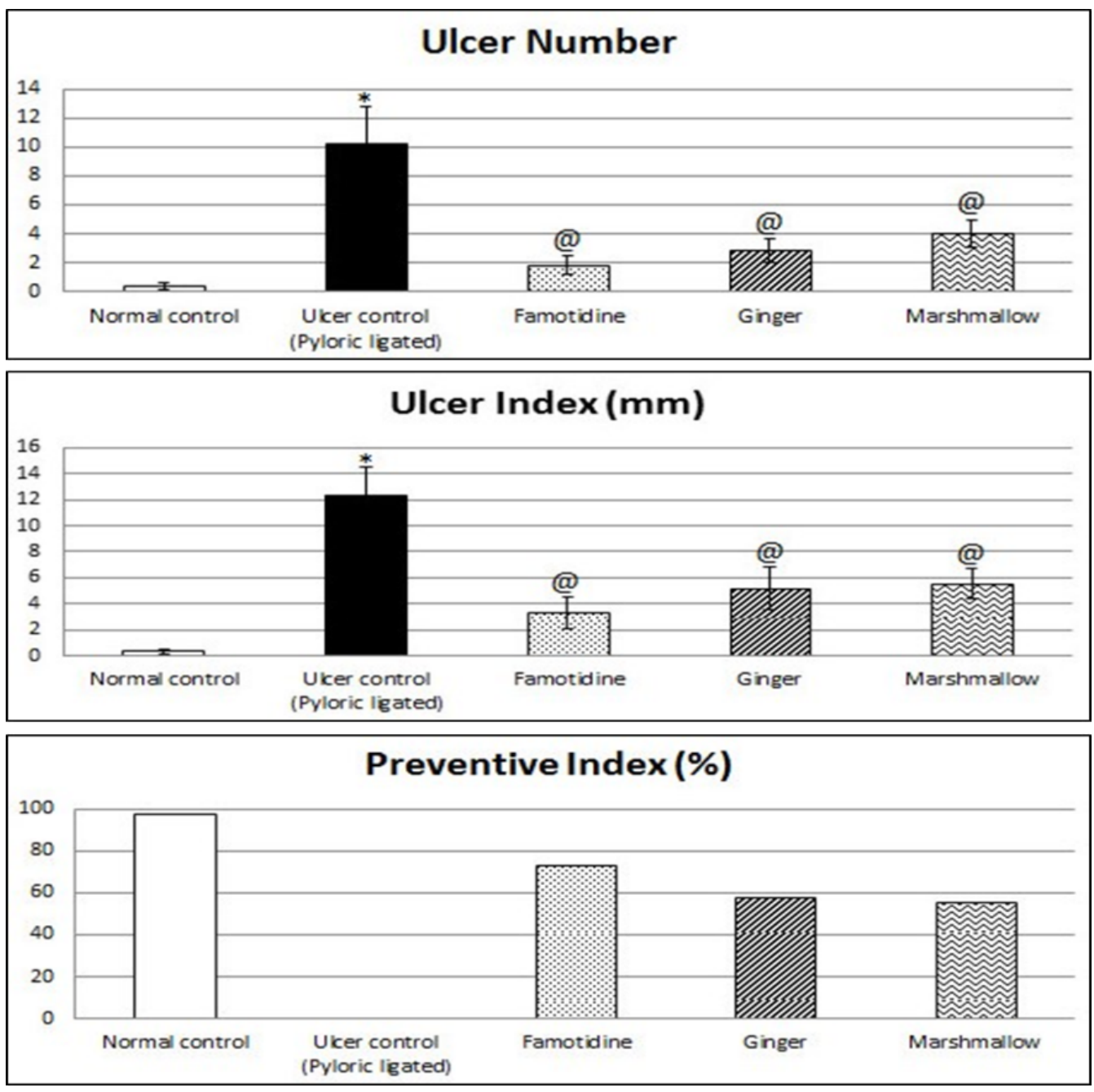

Figure 1: Protective effects of 14 days daily treatment with Famotidine, ginger and marshmallow on ulcer number, ulcer index and preventive index in pyloric ligationinduced gastric ulceration in rats. Each value represents the mean of 6-8 animals \pm standard error of the mean. Statistical analysis was determined using one-way ANOVA test followed by Tukey-Kramer multiple comparisons test. *Significantly different from normal control group ( $p<0.05)$. @Significantly different from ulcer control group ( $p<0.05)$. "Significantly different from famotidine (standard drug) treated group $(p<0.05)$. 
Citation: Zaghlool SS, Shehata BA, Abo-Seif AA, El-Latif HAA (2015) Comparison between the Protective Effects of Famotidine, Ginger and Marshmallow on Pyloric Ligation-Induced Peptic Ulcer in Rats. J Bioequiv Availab 7: 170-178. doi:10.4172/jbb.1000234

pretreatment significantly reduced ulcer number and ulcer index to about $39.37 \%$ and $44.6 \%$, respectively (Figure 1 ).

\section{Gastric volume, titratable acidity and acid output}

Rats subjected to pyloric ligation showed significant elevation in gastric volume, titratable acidity and acid output, reaching values of $1.75 \pm 0.37 \mathrm{ml} / 4 \mathrm{~h}, 73.688 \pm 6.26 \mathrm{mEq} / \mathrm{l}$ and $31.2 \pm 5.86 \mu \mathrm{Eq} / 4 \mathrm{~h}$, respectively. Pretreatment with famotidine did not significantly change gastric volume but significantly decreased titratable acidity and acid output to $27.37 \%$ and $23.14 \%$, respectively as compared to ulcer control group. Similarly ginger pretreatment did not significantly affect gastric volume, titratable acidity or acid output as compared to ulcer control group, but significantly increased titratable acidity and acid output to $340.83 \%$ and $537.25 \%$, respectively, as compared to famotidine (standard drug) treated group. In addition, marshmallow pretreatment did not significantly affect gastric volume, titratable acidity or acid output as compared to ulcer control group group but it significantly increased titratable acidity to $357.15 \%$ compared to famotidine (standard drug) treated group (Figure 2).

\section{Results of gastric acid secretion (Peptic activity and mucin concentration)}

Rats subjected to pyloric ligation (ulcer control rats) showed increase in glycoprotein content and peptic activity as it was $2.74 \pm 0.45$ $\mathrm{mg}$ hexose $/ \mathrm{ml}$ and $72.73 \pm 0.635 \mathrm{mg} / \mathrm{ml}$, respectively. Pretreatment with famotidine significantly decreased glycoprotein content and peptic activity to $21.53 \%$ and $87.47 \%$, respectively as compared to ulcer control group. Similarly, ginger pretreatment significantly decreased glycoprotein content and peptic activity to $21.13 \%$ and $89.54 \%$, respectively. In addition, marshmallow pretreatment did not significantly affect glycoprotein content but it significantly decreased peptic activity to $93.8 \%$. It also significantly increased glycoprotein content and peptic Activity to $337.28 \%$ and $107.23 \%$, respectively as compared to famotidine (standard drug) treated group. Also it significantly increased glycoprotein content and peptic activity to $343.69 \%$ and $104.76 \%$, respectively as compared to ginger treated group (Figure 3).
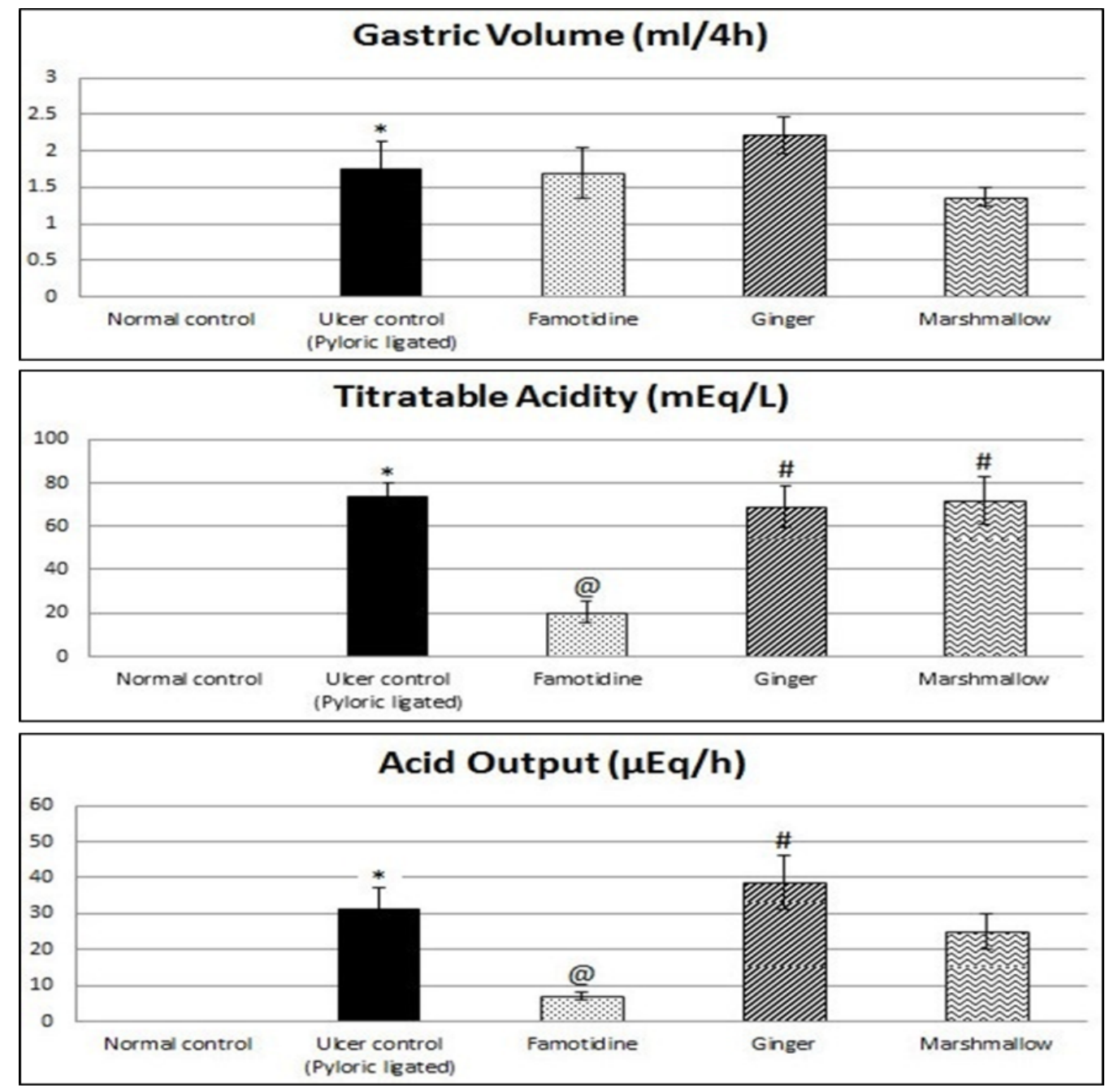

Figure 2: Protective effects of 14 days daily treatment with Famotidine, ginger and marshmallow on gastric volume, titratable acidity and acid output in pyloric ligationinduced gastric ulceration in rats. Each value represents the mean of 6-8 animals \pm standard error of the mean. Statistical analysis was determined using one-way ANOVA test followed by Tukey-Kramer multiple comparisons test. *Significantly different from normal control group ( $p<0.05)$. @Significantly different from ulcer control group $(p<0.05)$. "Significantly different from famotidine (standard drug) treated group $(p<0.05)$. 
Citation: Zaghlool SS, Shehata BA, Abo-Seif AA, El-Latif HAA (2015) Comparison between the Protective Effects of Famotidine, Ginger and Marshmallow on Pyloric Ligation-Induced Peptic Ulcer in Rats. J Bioequiv Availab 7: 170-178. doi:10.4172/jbb.1000234
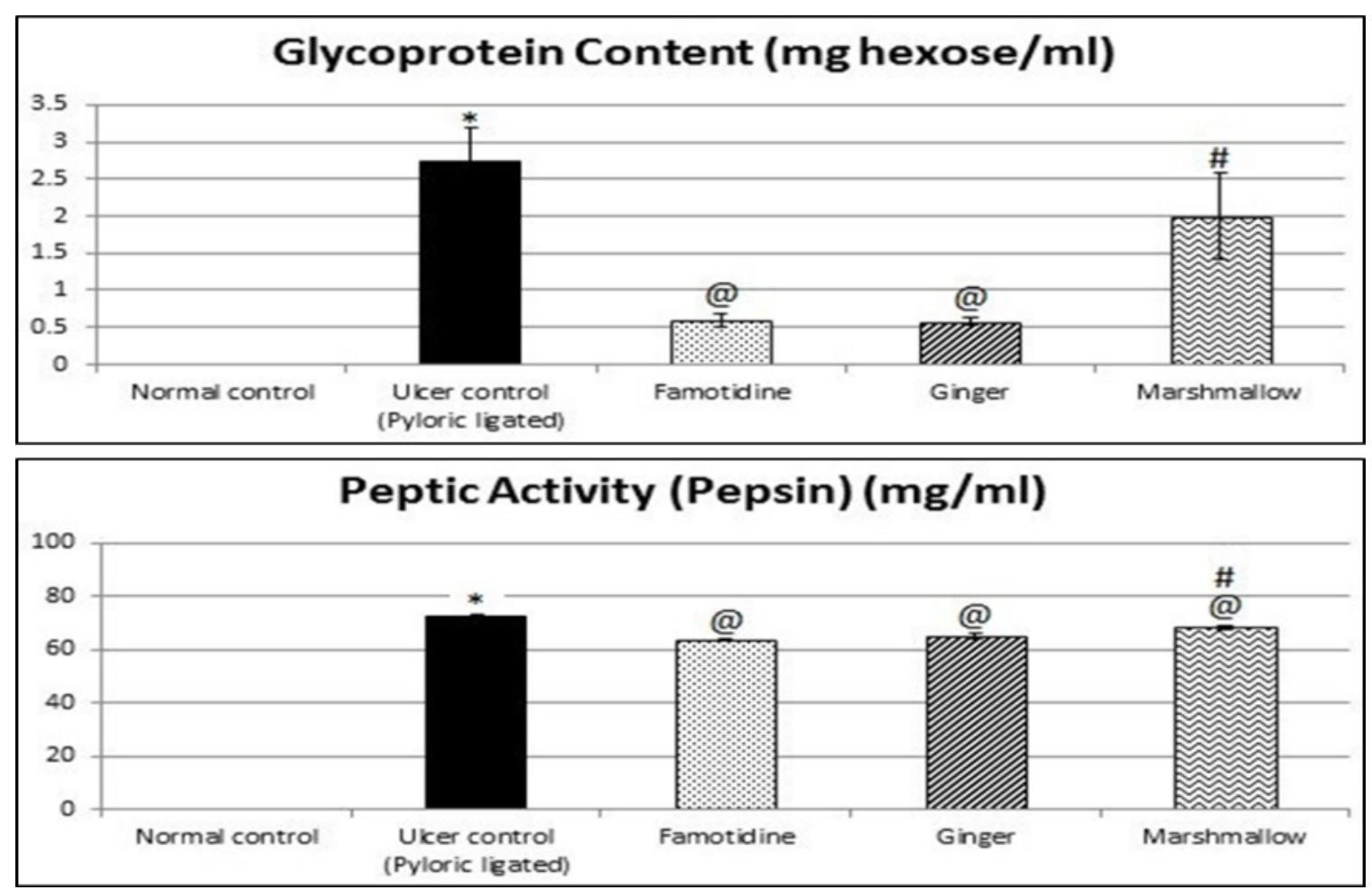

Figure 3: Protective effects of 14 days daily treatment with Famotidine, ginger and marshmallow on glycoprotein content and peptic activity in pyloric ligation-induced gastric ulceration in rats. Each value represents the mean of $6-8$ animals \pm standard error of the mean. Statistical analysis was determined using one-way ANOVA test followed by Tukey-Kramer multiple comparisons test. "Significantly different from normal control group ( $p<0.05)$. @Significantly different from ulcer control group $(p<0.05)$. "Significantly different from famotidine (standard drug) treated group $(p<0.05)$.

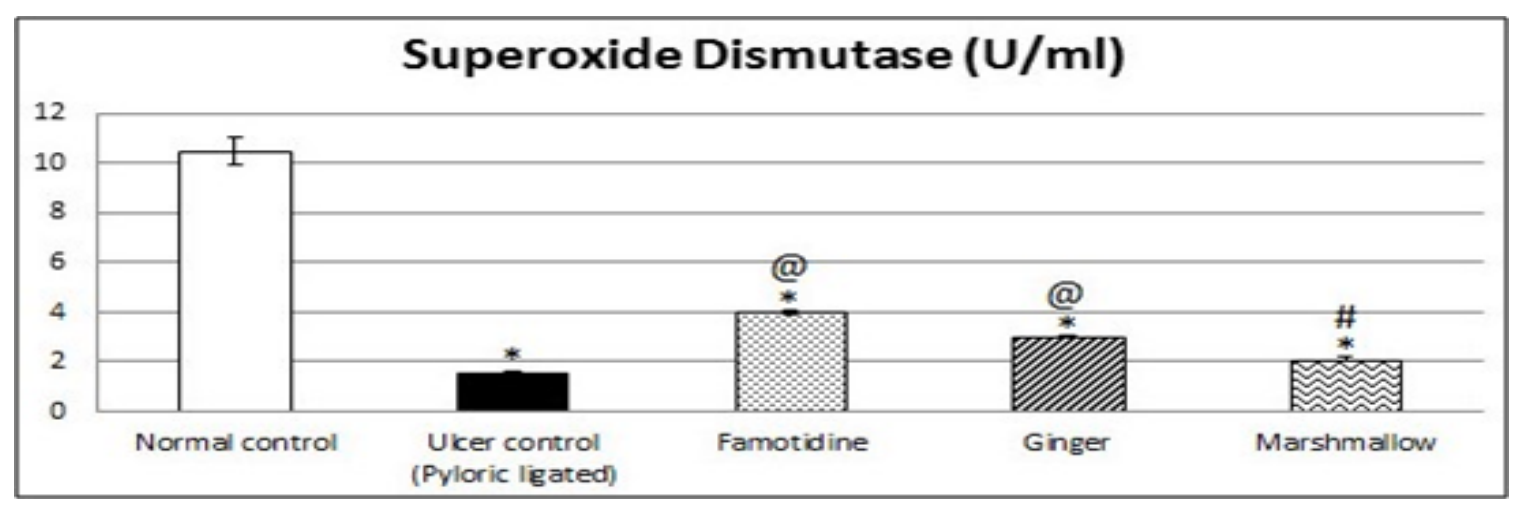

Figure 4: Protective effects of 14 days daily treatment with Famotidine, Ginger and Marshmallow on Superoxide Dismutase in Pyloric Ligation-induced gastric ulceration in rats. Each value represents the mean of $6-8$ animals \pm standard error of the mean. Statistical analysis was determined using one-way ANOVA test followed by Tukey-Kramer multiple comparisons test. 'Significantly different from normal control group $(p<0.05)$. @Significantly different from ulcer control group $(p<0.05)$. "Significantly different from famotidine (standard drug) treated group $(p<0.05)$.

\section{Results of on blood samples collected (Superoxide Dismutase Activity}

Rats subjected to pyloric ligation (ulcer control rats) showed significant decrease in SOD activity to $14.57 \%$ as compared to normal control rats. Pretreatment with famotidine significantly increased SOD activity to $262.95 \%$ as compared to ulcer control group. Ginger pretreatment significantly increased SOD activity to $198.69 \%$. In addition, marshmallow pretreatment did not significantly affect SOD activity as compared to ulcer control group but significantly decreased
SOD activity to $52.12 \%$ as compared to famotidine (standard drug) treated group (Figure 4).

Results of gastric mucosal tissues (Nitric oxide, Glutathione, Malondialdehyde and Histamine Content)

Rats subjected to pyloric ligation (ulcer control rats) showed significant decrease in GSH and NO content to $15.52 \%$ and $17.81 \%$, respectively and significantly increased MDA and histamine content to $655.43 \%$ and $689.94 \%$, respectively as compared to normal control rats. Pretreatment with famotidine significantly increased 
GSH and NO content to $289.77 \%$ and $387.56 \%$, respectively and significantly decreased MDA and histamine content to $27.72 \%$ and $27.04 \%$, respectively as compared to ulcer control group. Ginger pretreatment significantly increased GSH content and NO content to $234.1 \%$ and $298.92 \%$, respectively as compared to ulcer control group and significantly decrease NO content to $77.13 \%$ compared to famotidine (standard drug) treated group. It significantly decreased MDA and histamine content to $38.08 \%$ and $36.84 \%$, respectively as compared to ulcer control group and significantly increased MDA content to $137.38 \%$ compared to famotidine (standard drug) treated group. In addition, marshmallow pretreatment did not significantly affect GSH or NO content compared to ulcer control group but it significantly decreased GSH and NO content to $42.74 \%$ and $39.39 \%$, respectively as compared to famotidine (standard drug) treated group and it significantly decreased GSH and NO content to $52.91 \%$ and $51.07 \%$, respectively as compared to ginger treated group respectively. Marshmallow also significantly decreased MDA and histamine content to $76.69 \%$ and $75.71 \%$, respectively as compared to ulcer control group. It significantly increased MDA and histamine content to $276.68 \%$ and $279.94 \%$, respectively as compared to famotidine (standard drug) treated group and significantly increased MDA and histamine content to $201.39 \%$ and $205.49 \%$, respectively as compared to ginger treated group (Table 1).

\section{Histopathological examinations}

As shown in Figures 5a-5e, Histopathological examination of normal control rats' stomachs showed normal basic layers of the fundus can be distinguished (Figure 5a). Rats subjected to pyloric ligation (ulcer control rats) showed a severe disruption to the glandular epithelium and ulcer crater is clearly visible. Edema of the submucosal layer with lymphocytic infiltration was seen. Disrupted muscularis mucosa and inner circular layer of musculosa can also be noted (Figure 5b). Pretreatment with Famotidine showed nearly normal gastric mucosa with a small area of atrophied surface epithelium and exfoliation of few cells. The intact muscularis mucosa can be seen (Figure 5c). Ginger pretreatment showed that the damage is limited to the superficial epithelium with detachment of few cells and intact muscularis mucosa. Edema of submucosa is noticed (Figure 5d). Marshmallow pretreatment showed severe disruption to the glandular epithelium. Edema of the submucosal layer with inflammatory cells can notice and disrupted muscularis mucosa. Inner circular layer and outer longitudinal layer of musculosa are clearly observed (Figure 5e).

\section{Discussion}

Phytochemical screening of test substances (marshmallow and ginger) was performed prior to work. The phytochemical screening of alcoholic extract of ginger revealed the presence of carbohydrates, volatile oils, sterols and triterpenoids and alkaloids. Similar results were obtained by Ali et al. [40] and Arun et al. [16]. The phytochemical screening of aqueous extract of marshmallow revealed the presence of carbohydrates, volatile oils, tanins, flavonoids, and traces of saponins. Similar results have been reported by Al-Snafi [41].

Current investigation revealed that pyloric ligation for 4 hours caused significant ulceration in the glandular area of the rat stomach as seen in histopathological examination. This was associated by marked increase in ulcer number and ulcer index. Similar results were obtained by Singh et al. [15]. Pyloric ligation showed also significant increases in the gastric volume, titratable acidity and acid output. Similar results have been reported by Bhalke et al. [42] who demonstrated that pyloric ligation of rats for 4 hours resulted in accumulation of gastric secretory volume and increase in titrable acidity (reduction of $\mathrm{pH}$ of gastric juice) and gastric ulceration. An increase in glycoprotein content in gastric juice after pyloric ligation was observed, where similar results were obtained by Malash et al. [43]. Pyloric ligations showed increase in peptic activity in agreement with results have been reported by Rastogi et al. [44] and Malash et al. [43] who demonstrated increase in the pepsin activity in the gastric juice after pyloric ligation. Pyloric ligation-induced ulcer was associated by oxidative stress as seen by increased MDA and decreased SOD and GSH. Bafna and Balaraman [46] also observed a decrease in the activity of SOD in pyloric ligation model. Furthermore, pyloric ligation significantly increased histamine content, which is again in agreement with pervious results reported by Bharti et al. [17] showing gastric mucosal damage in the same model, which was attributed to the decrease in mucosal defense due to starvation and increased vagal discharge resulting in degranulation of mast cells and depletion of histamine in gastric tissue. Gastric ulcer induced by pyloric ligation is believed to be due to stress induced increased in gastric hydrochloric acid secretion and/or stasis of acid. According to Shay et al. [20] the volume of secretion is also an important factor in the formation of ulcer due to exposure of the unprotected lumen of the stomach to the accumulating acid $[15,46]$. Pyloric ligation-induced gastric ulcers occur because of an increase in acid-pepsin accumulation due to pyloric obstruction and subsequent mucosal digestion and breakdown of the gastric mucosal barrier [42,47]. Oxidative stress plays an important role in the pathogenesis of various diseases including

\begin{tabular}{|c|c|c|c|c|c|c|c|c|c|}
\hline \multirow[b]{2}{*}{ Group } & \multirow[b]{2}{*}{ Treatment } & \multicolumn{2}{|c|}{ Glutathione } & \multicolumn{2}{|c|}{ Nitric Oxide } & \multicolumn{2}{|c|}{ Malondialdehyde } & \multicolumn{2}{|c|}{ Histamine } \\
\hline & & $\mu \mathrm{mol} / \mathrm{g}$ tissue & $\begin{array}{c}\% \text { of } \\
\text { control } \\
\text { ulcer }\end{array}$ & $\mu \mathrm{mol} / \mathrm{g}$ tissue & $\begin{array}{c}\% \text { of } \\
\text { control } \\
\text { ulcer }\end{array}$ & $\mathrm{nmol} / \mathrm{g}$ tissue & $\begin{array}{c}\% \text { of } \\
\text { control } \\
\text { ulcer }\end{array}$ & ng/g tissue & $\begin{array}{c}\% \text { of } \\
\text { control } \\
\text { ulcer }\end{array}$ \\
\hline Group 1 & Normal control & $5.67 \pm 0.28$ & 644.32 & $182.77 \pm 9.29$ & 561.5 & $18.67 \pm 0.83$ & 15.26 & $1.79 \pm 0.06$ & 14.49 \\
\hline Group 2 & $\begin{array}{c}\text { Ulcer control } \\
\text { (Pyloric ligated) }\end{array}$ & $0.88 \pm 0.04^{*}$ & 100 & $32.55 \pm 2.52^{*}$ & 100 & $122.37 \pm 3.75^{*}$ & 100 & $12.35 \pm 0.46^{*}$ & 100 \\
\hline Group 3 & $\begin{array}{c}\text { Famotidine } \\
(20 \mathrm{mg} / \mathrm{kg}, \text { p.o. })\end{array}$ & $2.55 \pm 0.22^{*} @$ & 289.77 & $126.15 \pm 3.07^{*} @$ & 387.56 & $33.92 \pm 1.87^{*} @$ & 27.72 & $3.34 \pm 0.17^{*} @$ & 27.04 \\
\hline Group 4 & $\begin{array}{c}\text { Ginger } \\
\text { (100 mg/kg, p.o.) }\end{array}$ & $2.06 \pm 0.03^{*} @$ & 234.1 & $97.3 \pm 3.83^{*}$ & 298.92 & $46.6 \pm 2.25^{* @ \#}$ & 38.08 & $4.55 \pm 0.23^{*} @$ & 36.84 \\
\hline Group 5 & $\begin{array}{c}\text { Marshmallow } \\
(100 \mathrm{mg} / \mathrm{kg}, \text { p.o. })\end{array}$ & $1.09 \pm 0.02^{* \#}$ & 123.86 & $49.7 \pm 1.72^{* \#}$ & 152.69 & $93.85 \pm 4.4^{* @ \#}$ & 76.69 & $9.35 \pm 0.4^{* @ \# ~}$ & 75.71 \\
\hline
\end{tabular}

Each value represents the mean of 6-8 animals \pm standard error of the mean. Statistical analysis was determined using one-way ANOVA test followed by Tukey-Kramer multiple comparisons test. "Significantly different from normal control group $(p<0.05)$. ${ }^{@}$ Significantly different from ulcer control group ( $\left.p<0.05\right)$. \#Significantly different from famotidine (standard drug) treated group $(p<0.05)$.

Table 1: Protective effects of 14 days daily treatment with famotidine, ginger and marshmallow on nitric oxide, glutathione, malondialdehyde and histamine in pyloric ligation-induced gastric ulceration in rats. 
Citation: Zaghlool SS, Shehata BA, Abo-Seif AA, El-Latif HAA (2015) Comparison between the Protective Effects of Famotidine, Ginger and Marshmallow on Pyloric Ligation-Induced Peptic Ulcer in Rats. J Bioequiv Availab 7: 170-178. doi:10.4172/jbb.1000234

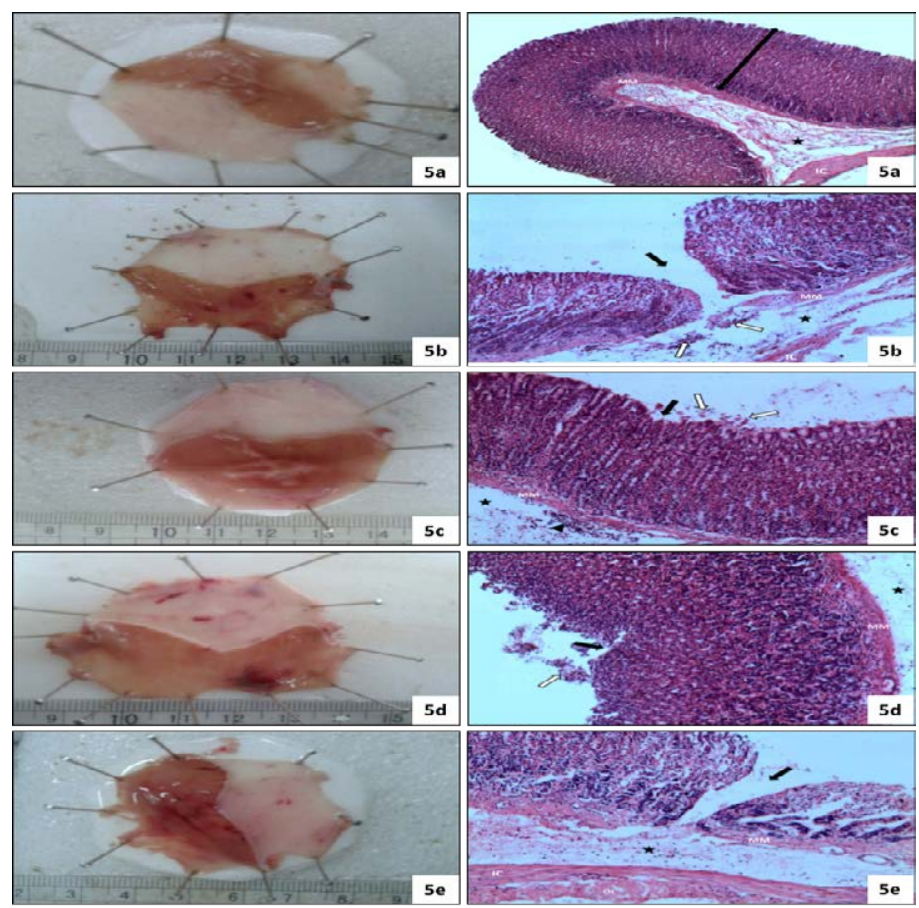

Figure 5: Images from stomachs and histopathological examination of each group.

a: Image from stomach and a photomicrograph of the fundus of group 1 normal control group.

b: Image from stomach and a photomicrograph of the fundus of group 2 - peptic ulcer control group (pyloric ligated).

c: Image from stomach and a photomicrograph of the fundus of group 3 - famotidine $(20 \mathrm{mg} / \mathrm{kg}, \mathrm{p} . \mathrm{o}$.)

$\mathrm{d}$ : Image from stomach and a photomicrograph of the fundus of group $4-$ ginger $(100 \mathrm{mg} / \mathrm{kg}, \mathrm{p} . \mathrm{o}$.).

e: Image from stomach and a photomicrograph of the fundus of group 5 - Marshmallow (100 mg/kg, p.o.). Where (white arrow) is lymphocytic infiltration or exfoliation

of few cells, (black arrow) is the glandular mucosa, $($ ) is the submucosal layer, (MM) is the muscularis mucosa, (IC) is the inner circular layer of musculosa and (OL)

is outer longitudinal layer.

gastric ulcer, with antioxidants being reported to play a significant role in the protection of gastric mucosa against various necrotic agents [45]. Reactive oxygen species are involved in the pathogenesis of pyloric ligation-induced gastric mucosal injury in vivo [44]. As compared to normal rats, pyloric ligation was found to increase lipid peroxidation and decrease SOD, CAT and GSH as compared to normal control groups, thus leading to oxidative stress. Preventive antioxidants, such as SOD and CAT enzymes are the first line of defense against reactive oxygen species [18]. GSH is a major low molecular weight scavenger of free radicals in the cytoplasm and an important inhibitor of free radical mediated lipid peroxidation $[18,45,48]$. NO is an endogenous defensive factor for gastric cells and exhibits gastroprotective properties against different types of aggressive agents [49]. It is involved in the maintenance of mucosal integrity through the regulation of mucus and alkaline secretion, gastric motility and microcirculation [50]. NO is known to modulate acid levels, gastric mucus secretion, and blood flow in gastric tissues. NO has also been reported to prevent membrane lipid peroxidation [51]. NO can increase gastric blood flow and mucus secretion $[52,53]$.

Gastric secretion in this model has been shown to be mediated through histamine and can be inhibited by $\mathrm{H}_{2}$ antagonists [54-56]. Results of the present study revealed that famotidine protected animals from pyloric ligation-induced gastric ulceration as manifested by significantly reduced the ulcer number and ulcer index. Ramachandran et al. [57] reported that famotidine reduced the ulcer index in aspirin and pyloric ligation-induced gastric ulcer models thus showing the antisecretory mechanism involved in the antiulcerogenic activity through $\mathrm{H}_{2}$ receptor blockade. Famotidine also significantly decreased titratable acidity and acid output after pyloric ligation. In addition famotidine produced a significant increase in the $\mathrm{pH}$ and decrease in the acidity of gastric secretions as well as significant decrease in glycoprotein content in gastric juice after pyloric ligation. Significant decrease in peptic activity was also observed. The antiulcer activity of famotidine was associated by reduction of oxidative stress as observed by reduction of MDA and marked increase in SOD and GSH. Bharti et al. [17] reported that famotidine normalized all the oxidative stress parameters (GSH, TBARS and SOD) in ethanol model, aspirin model and pyloric ligation model included in his study. Famotidine significantly increased NO content in pyloric ligation. Similar results have been reported by Dursun et al. [58] who observed an increased in the level of NO in stomach tissue from ranitidine treated rats. NO levels have been shown to be reduced in damaged stomach tissue [59]. Famotidine significantly decreased histamine content in pyloric ligation. Bharti et al. [17] observed that vagally induced gastric secretion in this model has been shown to be mediated through histamine and is inhibited by $\mathrm{H}_{2}$ antagonists. Therefore besides antagonizing $\mathrm{H}_{2}$-receptors, Famotidine has also been shown to exhibit oxygen radical scavenging properties [60].

Pretreatment with ginger showed antiulcer activity as seen by significant reduction of the ulcer number and ulcer index after pyloric ligation. These results further support that obtained by Al-Yahya et al. [61]. Ginger significantly decreased glycoprotein content in gastric juice after pyloric ligation. Furthermore, ginger extract significantly decreased peptic activity after pyloric ligation. Arun et al. [16] reported that Ethanol-induced depletion of gastric wall mucus has been significantly prevented by ginger. The antiulcer activity of ginger was 
Citation: Zaghlool SS, Shehata BA, Abo-Seif AA, El-Latif HAA (2015) Comparison between the Protective Effects of Famotidine, Ginger and Marshmallow on Pyloric Ligation-Induced Peptic Ulcer in Rats. J Bioequiv Availab 7: 170-178. doi:10.4172/jbb.1000234

associated by reduction of oxidative stress as observed by significant decrease of MDA and increase in GSH and SOD after pyloric ligation. It was reported by Mishra et al. [62] that Ginger oil might act as a scavenger of oxygen radical and might be used as an antioxidant. Likewise Wattanathorn et al. [63] reported that Zingiber officinale significantly decreased MDA level in cerebral cortex, striatum, and hippocampus. Similarly, Wattanathorn et al. [63] who determined that Zingiber officinale increased the activity of SOD in cerebral cortex, hippocampus, and striatum. One of the antiulcer activities of ginger could be due to the observed reduction of histamine release.

Marshmallow pretreatment showed antiulcer activity as observed by significant reduction of the ulcer number, ulcer index and peptic activity after pyloric ligation. Furthermore, marshmallow significantly reduced ulcer associated oxidative stress as manifested by significant decrease in MDA. Also histamine content was significantly decreased. Therefore the anti-ulcer effect of marshmallow could be attributed to reduction of oxidative stress and histamine release. The gastroprotective effect of marshmallow observed could be attributed to active compounds found in the extract such as flavonoids and mucilage polysaccharides [13]. Althaea officinalis L. has a mucus protection (cytoprotection effect) and an antioxidant effect [64,65].

According to the results of the present investigation, we can conclude that famotidine, ginger and marshmallow can protect against pyloric ligation induced ulcer.

\section{Acknowledgments and Conflict of Interest}

This work was supported by its authors and we have no conflict of interest.

\section{References}

1. Rao CV, Venkataramana K (2013) A Pharmacological Review on Natural Antiulcer Agents. J Global Trends Pharm Sci 4: 1118-1131.

2. Taha AS, Hudson N, Hawkey CJ, Swannell AJ, Trye PN, et al. (1996) Famotidine for the prevention of gastric and duodenal ulcers caused by nonsteroidal antiinflammatory drugs. N Engl J Med 334: 1435-1439.

3. Brunton LL, Lazo JS, Parker KL (2005) Pharmacotherapy of Gastric Acidity, Peptic Ulcers, and Gastroesophageal Reflux Disease. In: Goodman and Gilman's Pharmacological Basis of Therapeutics (11thedn.) McGraw-Hill Publication, New York, pp. 967-981.

4. Ahirrao VK, Pawar RP (2013) Simultaneous Quantification of Famotidine and Ibuprofen in Pharmaceutical Dosage by Using Validated Stability Indicating LC Method. Res J Pharm Sci 2: 1-9.

5. Qin Z, Chen C (2005) Synergistic action of famotidine and chlorpheniramine on acetic acid-induced chronic gastric ulcer in rats. World J Gastroenterol 11: 7203-7207.

6. Sharma VN (2007) Essentials of Pharmacology. Basic principles and general concepts (3rdedn.) CBS Publishers \& Distributors, New Delhi, Bangalore, p. 673.

7. Kumar MR, Niyas MK, Mani TT, Rahiman OMF, Kumar SB (2011) A review on medicinal plants for peptic ulcer. Der Pharmacia Lettre 3: 414-420.

8. Yamahara J, Huang Q (1990) Gastrointestinal motility enhancing effect of ginger and its active constituents. Chem Pharm Bull 38: 430-431.

9. Stewart JJ, Wood MJ, Wood CD, Mims ME (1991) Effects of ginger on motion sickness susceptibility and gastric function. Pharmacology 42: 111-120.

10. Banerjee S, Mullick HI, Banerjee J, Ghosh A (2011) Zingiber officinale: 'a natural gold'. Int J Pharm Bio Sci 2: 283-294.

11. Deters A, Zippel J, Hellenbrand N, Pappai D, Possemeyer C, et al. (2010) Aqueous extracts and polysaccharides from Marshmallow roots (Althea officinalis L.): Cellular internalisation and stimulation of cell physiology of human epithelial cells in vitro. J Ethnopharmacol 127: 62-69.

12. Izzo AA, Di-Carlo G, Mascolo N, Autore G, Capasso F (1994) Antiulcer effect of flavonoids, Role of endogenous PAF. Phytother Res 29: 87-93.
13. Hage-Sleiman R, Mroueh M, Daher CF (2011) Pharmacological evaluation of aqueous extract of Althaea officinalis flower grown in Lebanon. Pharm Biol 49: 327-333.

14. Harborne JB (2007) Phytochemical methods: A Guide to Modern Techniques of Plant Analysis. Chapman and Hall, London, UK.

15. Singh AP, Shukla V, Khare $P(2012)$ Effects of plumeria obtusa linn. in peptic ulcer induced by pylorus ligation \& indomethacin. J Pharm Sci Innov: 26-32.

16. Arun K, Vijayakumar VRCHM, Ayaz A, Naiyer S, Irfan KM (2010) Antiulcerogenic and ulcer healing effects of Zingiber officinale (L.) On experimental ulcer models: possible mechanism for the inhibition of acid formation. Int $\mathrm{J}$ Pharm Res 1: 75-85

17. Bharti S, Wahane VD, Kumar VL (2010) Protective effect of Calotropis procera latex extracts on experimentally induced gastric ulcers in rat. J Ethnopharmacol 127: 440-444.

18. Suleyman B, Halici Z, Odabasoglu F, Gocer F (2012) The effect of Lacidipine on Indomethacin induced ulcer in rats. Int J Pharmacol 8: 115-121.

19. El-Abhar HS, Hammad LN, Gawad HS (2008) Modulating effect of ginger extract on rats with ulcerative colitis. J Ethnopharmacol 118: 367-372.

20. Shay H, Komarow SA, Fels SS, Meranze D, Gruenstein M, et al. (1945) A simple method for the uniform production of gastric ulceration in the rat. Gastroenterology 5: 43-61.

21. Pendley CE, Fitzpatrick LR, Ewing RW, Molino BF, Martin GE (1993) The gastrin/cholecystokinin-B receptor antagonist L-365,260 reduces basal acid secretion and prevents gastrointestinal damage induced by aspirin, ethanol and cysteamine in the rat. J Pharmacol Exp Ther 265: 1348-1354.

22. Khayyal MT, el-Ghazaly MA, Kenawy SA, Seif-el-Nasr M, Mahran LG, et al (2001) Antiulcerogenic effect of some gastrointestinally acting plant extracts and their combination. Arzneimittelforschung 51: 545-553.

23. Cho $\mathrm{CH}$, Ogle CW (1979) Cholinergic-mediated gastric mast cell degranulation with subsequent histamine $\mathrm{H}$ 1-and $\mathrm{H} 2$-receptor activation in stress ulceration in rats. Eur J Pharmacol 55: 23-33.

24. Hano J, Bugajski J, Danek L, Wantuch C (1976) The effect of neuroleptics on the development of gastric ulcers in rats exposed to restraint-cold stress. Pol J Pharmacol Pharm 28: 37-47.

25. Shay $H$, Sun DC, Gruenstein M (1954) A quantitative method for measuring spontaneous gastric secretion in the rat. Gastroenterology 26: 906-913.

26. Grossman MI (1963) Physiology for physician. A monthly Publication of the American Physiological Society, 1: 1-5.

27. Brodie DA, Hooke KF (1971) The effect of vasoactive agents on stress-induced gastric hemorrhage in the rat. See comment in PubMed Commons below Digestion 4: 193-204.

28. Jorgensen MB (1954) A modified method for the determination of pepsinogen in urine (uropepsin). Scand J Clin Lab Invest 6: 303-310.

29. Winzler RJ (1955) Determination of serum glycoproteins. In: Glick DP (ed.) Methods of Biochemical Analysis. Interscience Publishers, New York, USA pp. 279-311.

30. Demoly P, Lebel B, Messaad D, Sahla H, Rongier M, et al. (1999) Predictive capacity of histamine release for the diagnosis of drug allergy. Allergy 54: $500-$ 506

31. Wiley J (1999) In: Michael G (ed.) Biochemical Pathways: An atlas of biochemistry and molecular biology. New York, USA, p. 246.

32. Anderson ME (1996) In: Punchard N, Kelly FJ (eds.) Glutathione in Free radicals: A Practical Approach. Oxford University Press, New York, pp. 213226.

33. Halliwell B, Gutteridge JMC (1999) Free Radicals in Biology and Medicine (3rdedn.) Oxford University Press, New York.

34. Li LF, Kao KC, Yang CT, Huang CC, Liu YY (2012) Ethyl pyruvate reduces ventilation-induced neutrophil infiltration and oxidative stress. Exp Biol Med (Maywood) 237: 720-727.

35. Troncoso Brindeiro CM, Lane PH, Carmines PK (2012) Tempol prevents altered $\mathrm{K}(+)$ channel regulation of afferent arteriolar tone in diabetic rat kidney. Hypertension 59: 657-664.

36. Kendrich KM, Guevara-Guzman R, Zorrilla J, Hinton MR, Broad KD, et al. 
Citation: Zaghlool SS, Shehata BA, Abo-Seif AA, El-Latif HAA (2015) Comparison between the Protective Effects of Famotidine, Ginger and Marshmallow on Pyloric Ligation-Induced Peptic Ulcer in Rats. J Bioequiv Availab 7: 170-178. doi:10.4172/jbb.1000234

(1997) Formation of olfactory memories mediated by nitric oxide. Nature 388: 670-674.

37. Connell BJ, Saleh MC, Khan BV, Rajagopal D, Saleh TM (2012) UPEI-100, a conjugate of lipoic acid and apocynin, mediates neuroprotection in a rat mode of ischemia/reperfusion. Am J Physiol Regul Integr Comp Physiol 302: R886895.

38. Zhang Z, Zhang W, Jung DY, Ko HJ, Lee Y, et al. (2012) TRPM2 Ca2+ channe regulates energy balance and glucose metabolism. Am J Physiol Endocrinol Metab 302: E807-816.

39. Drury RA, Wallington EA (1980) Carleton's Histological Techniques (6thedn.) Oxford University Press, London, p. 183.

40. Ali BH, Blunden G, Tanira MO, Nemmar A (2008) Some phytochemical, pharmacological and toxicological properties of ginger (Zingiber officinale Roscoe): a review of recent research. Food Chem Toxicol 46: 409-420.

41. Al-Snafi AE (2013) The pharmaceutical importance of Althaea officinalis and Althaea rosea: A Review. Int J Pharm Technol Res 5: 1378-1385.

42. Bhalke RD, Giri MA, Anarthe SJ, Pal SC (2010) Antiulcer activity of the ethano extract of leaves of sesbania grandiflora (linn.). Int J Pharm Pharm Sci 2: 206208

43. Malash AM, Abdallah DM, Agha AM, Kenawy SA (2012) Gastroprotective Efficacy of Coenzyme Q10 in Indomethacin-Induced Gastropathy: Other Potential Mechanisms. Ulcers 2012: 1-7.

44. Rastogi L, Patnaik GK, Dikshit M (1998) Free radicals and antioxidant status following pylorus ligation induced gastric mucosal injury in rats. Pharmacol Res 38: $125-132$.

45. Bafna PA, Balaraman R (2011) Effect of activit, a herbomineral formulation, on experimentally-induced gastric lesions in rats. J Appl Pharm Sci 1: 134-139.

46. Bhave AL, Bhatt JD, Hemavathi KG (2006) Antiulcer effect of amlodipine and its interaction with $\mathrm{H} 2$ blocker and proton pump inhibitor in pylorus ligated rats. Ind J Pharmacol 38: 403-407.

47. Sairam K, Rao ChV, Babu MD, Kumar KV, Agrawal VK, et al. (2002) Antiulcerogenic effect of methanolic extract of Emblica officinalis: an experimental study. J Ethnopharmacol 82: 1-9

48. Halliwell B (1995) Antioxidant characterization. Methodology and mechanism. Biochem Pharmacol 49: 1341-1348.

49. Samini M, Moezi L, Jabarizadeh N, Tavakolifar B, Shafaroodi H, et al. (2002) Evidences for involvement of nitric oxide in the gastroprotective effect of bromocriptine and cyclosporin A on water immersion stress-induced gastric lesions. Pharmacol Res 46: 519-523.

50. Tsukimi Y, Okabe S (2001) Recent advances in gastrointestinal pathophysiology: role of heat shock proteins in mucosal defense and ulcer healing. Biol Pharm Bull 24: 1-9.
51. Abdallah IZA, Khattab HAH, Heeba GH (2011) Gastroprotective Effect of Cordia Myxa L. Fruit Extract against Indomethacin-Induced Gastric Ulceration in Rats. Life Sci J 8: 433-445.

52. 52. Martín MJ, Jiménez MD, Motilva V (2001) New issues about nitric oxide and its effects on the gastrointestinal tract. Curr Pharm Des 7: 881-908.

53. Nabavizadeh F, Alizadeh AM, Adeli S, Golestan M, Moloudian H, et al. (2011) Gastroprotective effects of Stachys Lavandulifolia extract on experimental gastric ulcer. Afr J Pharm Pharmacol 5: 155-159.

54. Ganguly AK, Gopinath P (1979) Vagus nerves and the gastric tissue histamine concentration in pylorus ligated albino rats. Q J Exp Physiol Cogn Med Sci 64 $1-6$

55. Salim AS (1989) The role of vagal adrenergic activity in the mechanism of gastric acid secretion after pylorus-ligation in the rat. J Pharm Pharmacol 41 : 566-568.

56. Andersson K, Chen D, Mattsson H, Sundler F, Håkanson R (1998) Physiological significance of ECL-cell histamine. Yale J Biol Med 71: 183-193.

57. Ramachandran S, Poovi G, Dhanaraju MD (2011) Evaluation of Gastric and Duodenal Antiulcer Activity of Famotidine Formulation in Experimental Animals. J Pharmacol Toxicol 6: 189-195.

58. Dursun H, Bilici M, Albayrak F, Ozturk C, Saglam MB, et al. (2009) Antiulce activity of fluvoxamine in rats and its effect on oxidant and antioxidant parameters in stomach tissue. BMC Gastroenterol 9: 36 .

59. Cadirci E, Suleyman H, Aksoy H, Halici Z, Ozgen U, et al. (2007) Effects of Onosma armeniacum root extract on ethanol-induced oxidative stress in stomach tissue of rats. Chem Biol Interact 170: 40-48.

60. Lapenna D, De Gioia S, Mezzetti A, Grossi L, Festi D, et al. (1994) H2-receptor antagonists are scavengers of oxygen radicals. Eur J Clin Invest 24: 476-481.

61. al-Yahya MA, Rafatullah S, Mossa JS, Ageel AM, Parmar NS, et al. (1989) Gastroprotective activity of ginger zingiber officinale rosc., in albino rats. Am J Chin Med 17: 51-56.

62. Mishra RK, Kumar A, Kumar A (2012) Review Article: Pharmacological Activity of Zingiber Officinale. Int J Pharm Chem Sci 1: 1073-1078.

63. Wattanathorn J, Jittiwat J, Tongun T, Muchimapura S, Ingkaninan K (2010) Zingiber officinale mitigates brain damage and improves memory impairmen in focal cerebral ischemic rat. Evid Based Complement Alternat Med: 2011.

64. Farzaei MH, Rahimi R, Abbasabadi Z, Abdollahi M (2013) An Evidence-based Review on Medicinal Plants used for the Treatment of Peptic Ulcer in Traditional Iranian Medicine. Int J Pharmacol 9: 108-124.

65. Suleyman H, Cadirci E, Albayrak A, Polat B, Halici Z, et al. (2009) Comparative study on the gastroprotective potential of some antidepressants in indomethacininduced ulcer in rats. Chem Biol Interact 180: 318-324. 